\title{
Ex vivo and in vivo study of Kowa HA-2 applanation tonometer in the measurement of intraocular pressure in cats
}

\author{
Estudo ex vivo e in vivo do uso do tonômetro de aplanação Kowa \\ HA-2 na medição da pressão intraocular em gatos
}

\author{
Claudia Lizandra Ricci ${ }^{1}$; Rogério Giuffrida ${ }^{2}$; Glaucia Prada Kanashiro ${ }^{3}$; Hilidia \\ Stephania Rufino Belezzi ${ }^{4}$; Carolina de Carvalho Bacarin ${ }^{4}$; Michele Paulo Tenório4; \\ Bruna Toledo Duran Foglia ${ }^{4}$; Silvia Franco Andrade ${ }^{5 *}$
}

\begin{abstract}
The objective of this study was to evaluate the use of the Kowa HA-2 applanation tonometer in measuring intraocular pressure (IOP) in cats. Ten healthy eyes were used in an ex vivo study in which the calibration curve for manometry vs. tonometry was determined by artificially raising the IOP in 5 $\mathrm{mmHg}$ increments up to $60 \mathrm{mmHg}(10-60 \mathrm{mmHg})$. Both eyes of 10 anesthetized cats were studiedin vivo to compare manometry vs. tonometry. In the ambulatory study, 78 healthy eyes, 7 eyes with glaucoma and 20 eyes with uveitis were evaluated by tonometry, which was performed with topical anesthesia and $1 \%$ fluorescein eye drops for the formation of fluorescein semicircles. The correlation coefficient $\left(\mathrm{r}^{2}\right)$ between the manometer and the Kowa HA-2 tonometer was 0.993 and the linear regression equation was $\mathrm{y}=0.0915 \mathrm{x}+0.0878$ in the ex-vivo study. In the in vivo study, the IOP values (mean $\pm \mathrm{SD}$, in $\mathrm{mmHg}$ ) in manometry were $15.6 \pm 1.1(14.0-17.5)$ and in tonometry were $15.5 \pm 1.2(13.5-17.2)$, with no significant difference $(\mathrm{P}>0.05)$ between manometry and tonometry. In ambulatory study, using the Kowa HA-2 tonometer, the IOP values (mean $\pm \mathrm{SD}$, in $\mathrm{mmHg}$ ) were $15.0 \pm 1.5(11.8-18.3)$ for the healthy eyes, $38.4 \pm 8.1(29.6-53.7)$ for glaucomatous eyes and $10.4 \pm 2.0(5.3-12.2)$ for eyes with uveitis. There was a strong correlation and accuracy between the IOP values with the manometry and the Kowa HA-2 tonometer. In the ambulatorystudy the IOP values obtained with the tonometer were compatible for animals with healthy eyes and with clinical signs of glaucoma and uveitis. We conclude that the Kowa HA-2 tonometer can be used in the measurement of IOP in cats, since it is a practical and accurate method in this species.
\end{abstract}

Key words: Applanation tonometer. Ocular manometry. Intraocular pressure. Cats.

\section{Resumo}

O objetivo deste estudo foi avaliar o uso do tonômetro de aplanação Kowa HA-2 na aferição da pressão intraocular (PIO) em gatos. Dez olhos saudáveis foram utilizados em um estudo ex vivo no qual a curva

\footnotetext{
1 Discente, Mestrado em Ciência Animal, Curso de Medicina Veterinária, Universidade do Oeste Paulista, UNOESTE, Presidente Prudente, SP, Brasil. E-mail: clau_lizandra@yahoo.com.br

2 Prof. Dr., Departamento de Bioestatística, Curso de Medicina Veterinária, UNOESTE, Presidente Prudente, SP, Brasil. E-mail: rgiuffrida@unoeste.br

${ }^{3}$ Prof $^{a}$ M.e, Departamento de Anestesiologia, Curso de Medicina Veterinária, UNOESTE, Presidente Prudente, SP, Brasil. E-mail: prada@unoeste.br

${ }^{4}$ Discentes, Curso de Curso de Medicina Veterinária, UNOESTE, Presidente Prudente, SP, Brasil. E-mail: hilidiabelezzi_17@ hotmail.com; carolbacarin_92@hotmail.com; micheletenorio13@hotmail.com; buhfoglia@gmail.com

5 Prof ${ }^{\mathrm{a}}$ Dra $^{\mathrm{a}}$, Departamento de Clínica Médica de Pequenos Animais, Curso de Medicina Veterinária, e Programa de Pós-Graduação Mestrado e Doutorado em Ciência Animal, UNOESTE, Presidente Prudente, SP, Brasil. E-mail: silviafranco@unoeste.br

* Author for correspondence
} 
de calibração para manometria versus tonometria foi determinada por elevação artificial da PIO em incrementos de $5 \mathrm{mmHg}$ até $60 \mathrm{mmHg}(10-60 \mathrm{mmHg})$. Ambos os olhos de 10 gatos anestesiados foram utilizados no estudo in vivo para comparar a manometria versus a tonometria. No estudo ambulatorial, 78 olhos saudáveis, 7 olhos com glaucoma e 20 olhos com uveíte foram avaliados pela tonometria, que foi realizada com anestesia tópica e colírio de fluoresceína a $1 \%$ para a formação de semicírculos de fluoresceína. O coeficiente de correlação $\left(\mathrm{r}^{2}\right)$ entre o manômetro e o tonômetro Kowa HA-2 foi de 0,993 e a equação de regressão linear foi $\mathrm{y}=0,0915 \mathrm{x}+0,0878$ no estudo ex-vivo. No estudo in vivo, os valores de PIO (média \pm DP, em mmHg) na manometria foram de 15,6 $\pm 1,1(14.0-17.5)$ e na tonometria foi de $15,5 \pm 1,2(13.5-17.2)$, sem diferença significativa $(\mathrm{P}>0,05)$ entre manometria e tonometria. No estudo ambulatorial, com o tonômetro Kowa HA-2, os valores de PIO (média \pm DP, em mmHg) foram 15,0 \pm 1,5(11.8-18.3) para os olhos saudáveis, 38,4 $\pm 8,1(29.6-53.7)$ para os olhos glaucomatosos e 10,4 \pm 2,0(5.3 -12.2) para os olhos com uveíte. Houve uma forte correlação e acurácia entre os valores de PIO com a manometria eo tonômetro Kowa HA-2. No estudo ambulatorial os valores de PIO obtidos com o tonômetro foram compatíveis para animais com olhos saudáveis e com sinais clínicos de glaucoma e uveíte. Conclui-se que o tonômetro Kowa HA-2 pode ser utilizado na medição da PIO em gatos, por ser um método prático e preciso nessa espécie.

Palavras-chave: Tonômetro de aplanação. Manometria ocular. Pressão intraocular. Gatos.

\section{Introduction}

Tonometry is the measurement of intraocular pressure (IOP) using specific instruments called tonometers. Tonometers are an important tool in the diagnosis of eye diseases that can lead to irreversible blindness, for example, diseases that cause increases in pressure, such as glaucoma, or reductions in pressure, such as uveitis (OKAFOR; BRANDT, 2015; FEATHERSTONE; HEINRICH, 2013; VINCENT et al.., 2012; SCHOTTENSTEIN, 1996).

In all species, glaucoma is an ophthalmopathy that is characterized by progressive neuropathy that involves several pathophysiological processes that are typically associated with increased IOP. The pathophysiological process of glaucomatous optic neuropathy is likely to be a multifactorial event. An increase in IOP is the principal risk factor for glaucoma, and the primary goal of treatment is to reduce IOP to a value that prevents the death of retinal ganglion cells (XU et al., 2014; STRUEBING; GEISERT, 2015; TEIXEIRA et al., 2014; MILLER, 2013; MCLELLAN; MILLER, 2011).

Uveitis is an intraocular inflammation that causes IOP reductions and involves the uveal structures. In cats, the causes of glaucoma are usually secondary to anterior uveitis, trauma, cancer and lens dislocation, and the causes of uveitis are primarily infection and trauma, but there are other causes, such as high blood pressure and tumors. Cats, dogs and humans may acquire glaucoma and uveitis via various etiologies, and these species of animals can serve as experimental models for ocular studies (COLITZ, 2005; SHUKLA; PINARD, 2012; STILES, 2013; LEE et al., 2014).

The normal feline IOP varies according to the time of day, age and reproductive status. Normal cats exhibit a pronounced circadian rhythm in IOP with higher values during the night and a gradual decline that occurs during the day (DEL SOLE et al., 2007; KROLL et al., 2001; OFRI et al., 2002). In a study with 538 cats, the mean IOP was found to be $12.3 \pm 4.0 \mathrm{mmHg}$, and age was found to influence IOP; the IOP was found to be considerably lower in geriatric animals than in young cats, lower in adolescents than in adults, and lower in smaller cats and younger kittens within the first weeks of life than in adolescent cats (KROLL et al., 2001).

Tonometers can be used with or without direct contact, the instruments can be fixed or portable, and the principal methodology employed can be applanation, indentation or rebound (OKAFOR; BRANDT, 2015; VINCENT et al., 2012; SCHOTTENSTEIN, 1996; ELMALLAH; ASRANI, 2008; MAGGS, 2013). In cats, the 
most commonly used tonometers are portable, e.g., the Tonopen applanation tonometer and more recently the Tonovet, which is a portable rebound tonometer (MAGGS, 2013; MILLER et al., 1991; MCLELLAN et al., 2013; PASSAGLIA et al., 2004). There are few reports about the use of portable applanation tonometers that use the Goldmann methodology, such as the Perkins and Kowa HA-2 tonometers, in animals (ANDRADE et al., 2009; ANDRADE et al., 2011; ANDRADE et al., 2012; ANDRADE et al., 2013; ANDRADE et al., 2016), and these tonometers are very useful in humans (SCHOTTENSTEIN, 1996). Studies with the Perkins tonometer in animals have been conducted in dogs and cats (ANDRADE et al., 2009; ANDRADE et al., 2012), horses and cattle (ANDRADE et al., 2011; ANDRADE et al., 2013), and there is only one study that describes the use of the Kowa HA-2 tonometer in dogs (ANDRADE et al., 2016).

Thus, the objective of this study was to evaluatethe use of the Kowa HA-2 tonometer in cats analyzing the calibrationthrough an ex vivo study, the accuracythrough an in vivo study and the validation of this tonometer through anambulatory study.

\section{Materials and Methods}

This study was approved by the Ethics Committee on Animal Use (CEUA) of UNOESTE (Protocol No. 1777) and was conducted according to the rules of the Brazilian College of Animal Experimentation (COBEA), the Federal Council of Veterinary Medicine of Brazil (CFMV), and the Statement for the Use of Animals in Ophthalmic and Vision Research of the Association for Research in Vision and Ophthalmology (ARVO).

\section{Ex-vivo study}

To calibrate the Kowa HA-2 tonometer (Kowa, Japan), anex-vivostudy was performed on 10 healthy eyes of 5 cats (age $3.5 \pm 1.6(2.0-6.0)$ years, weight $3.5 \pm 1.1(2.0-5.0) \mathrm{kg}, 2$ males and 3 females) that died in the veterinary hospital and were authorized for necropsy by the Pathological Anatomy Service. In this study, the IOP values measured using ocular manometry were compared with the values measured using the tonometer. The eyelids were isolated with a blepharostat, and the anterior chamber was cannulated with a 23-gauge scalp vein needle (Embramac, Brazil) through the cornea approximately 1-2 $\mathrm{mm}$ from the limbus in the supero-lateral quadrant at the 10 o'clock position in the right eye (OD) and the 2 o'clock position in the left eye (OS). Cyanoacrylate glue (Superbond, Loctite, Itapevi, SP, Brazil) was applied around the needle to prevent leakage of the aqueous humor. The needle was connected via a polyethylene tube to a three-way stopcock that was also connected to a $10-\mathrm{mL}$ reservoir (syringe) filled with physiologic saline solution (Fresenius Kabi, Campinas, SP, Brazil) and to an aneroid manometer (Missouri, São Paulo, SP Brazil) that was at the zero position relative to the center of the eye. The calibration curves for manometry and tonometry was determined by artificially increasing the IOP in $5-\mathrm{mmHg}$ increments up to $60 \mathrm{mmHg}(10-60$ $\mathrm{mmHg}$ ) in the open stopcock mode. Three readings were taken with the tonometer at each level and averaged. Fluorescein 1\% eye drops (1\% sodium fluorescein, Allergan, Brazil) were applied prior to the readings. The tonometer was turned off after each measurement to zero it and subsequently calibrated according to the manufacturer's instructions.

\section{In vivo study}

To evaluate the accuracy, an in vivo study was performed in anesthetized animals comparing IOP using ocular manometry to those obtained with tonometer. Twenty healthy eyes of 10 healthy cats (age $3.6 \pm 1.1(2.0-5.0)$ years, weight $3.0 \pm$ 0.5 (2.1 to 3.6$) \mathrm{kg}, 3$ males and 7 females) from a cattery were used. The animals were anaesthetized 
using the following protocol: premedication with acepromazine $(0.2 \%$ Acepran, Vetnil, Brazil) at a dose of $0.05 \mathrm{mg} / \mathrm{kg}$ IV followed by induction with propofol (Propovan, Cristália, Brazil) at a dose of $5 \mathrm{mg} / \mathrm{kg}$ IV. Next, the animals were intubated with an endotracheal tube for the anesthesia maintenance with isoflurane (Biochimico, Brazil) diluted in $100 \% \mathrm{O} 2$. The animals were maintained on artificial ventilation, and the respiratory parameters were adjusted to maintain a final concentration of expired carbon dioxide (EtCO2) between 35-45 mmHg. To centralize the eyeball, the neuromuscular blocking drug atracurium besylate $(10 \mathrm{mg} / \mathrm{ml}$; Atracurium, Cristalia, Brazil) was used at a dose of $0.1 \mathrm{mg} / \mathrm{kg}$ IV.

The cornea was topically anaesthetized with 1 drop of $1 \%$ tetracaine hydrochloride eye drops with phenylephrine hydrochloride $(0.1 \%$; Anestésico, Allergan, Brazil). One drop of $1 \%$ fluorescein eye drops was introduced, and three IOP readings were taken with the Kowa HA-2 tonometer. The mean of these readings was calculated and multiplied by 10 in agreement with the calibrations obtained in the exvivostudy. After the tonometry, ocular manometry was performed to detect the IOP as described in the ex-vivostudy. Disinfection of the prism was performed after the use of the tonometer to prevent the transmission of ocular diseases. The prism was removed and washed in $0.9 \%$ saline solution and then immersed for 5 minutes in 3\% hydrogen peroxide solution, washed again in saline solution and dried with sterile gauze (LINGEL; COFFEY, 1992). After the IOP readings with manometry, the scalp was removed and with the aid of the end of a $25 \times 7$ $\mathrm{mm}$ needle, 1 drop of cyanoacrylate adhesive was applied to the puncture site in the cornea to seal the perforation. After this procedure, the animals were treated twice a day with single drop of diclofenacbased anti-inflammatory eye drops (Still, Allergan, Brazil) and three times a day with single drop of tobramycin-based antibiotic eye drops (Tobralox, EMS, Brazil) for 7 days and were evaluated with daily ophthalmic examinations(pupillary light reflex, slit-lamp biomicroscopy, Schirmer tear test and fluorescein test).

\section{Ambulatory study}

To validate the clinical use of the tonometer, an ambulatory study was performed in 78 healthy eyes of 39 healthy cats (age $2.3 \pm 1.3$ (1.0 to 6.0) years, $2.2 \pm 1.1(0.5-5.0) \mathrm{kg}, 12$ males and 27 females $), 7$ eyes of 5 cats (age $4.3 \pm 1.4(3.0-6.0)$ years, weight $4.1 \pm 0.7$ (3.0-5.0) kg, 3 males and 2 females) with one or more clinical signs of glaucoma (i.e., congested episcleral vessels, blepharospasm, visual disturbances, corneal edema, buftalmia, fixed dilated pupil, changes in the anterior chamber, lens dislocation, retinal degeneration, and optic disc cupping), and 20 eyes of 11 cats (age $3.9 \pm 2.5$ (1.0 to 8.0 ) years, weight $4.1 \pm 1.1$ (2.5 to 6.0$) \mathrm{kg}$, 5 males and 6 females) with one or more clinical signs of uveitis (i.e., photophobia, blepharospasm, pain, epiphora, aqueous flare, keratic precipitates, hypopyon, hyphema, ciliary injection, corneal edema, miosis, and anterior or posterior synechiae) from the ophthalmology ambulatory service for small animals in the Veterinary Hospital of UNOESTE.

For the IOP reading procedure with the Kowa HA-2 tonometer (Figure 1), one drop of anesthetic and fluorescein eye drop were administered to both eyes. Next, the excess fluorescein was removed with gauze, and the tonometer was placed in position 1 prior to the first reading. To position the tonometer over the cornea, adjustments of the semicircles for the IOP reading were performed and multiplied by 10 . After the tonometry, the eyes were cleaned with $0.9 \%$ saline solution. The tonometer was turned off after each measurement to zero it, and prism disinfection and instrument calibration were performed as described above. 
Figure 1. Ambulatory study. IOP reading procedure with the Kowa HA-2 tonometer in a cat. (a) Administration of 1 drop of an anesthetic eye drop. (b) Administration of 1 drop of a fluorescein eye drop. (c) Tonometry with adjustment of the semicircles. (d) Visualization of the semicircles of fluorescein on the tonometer display.

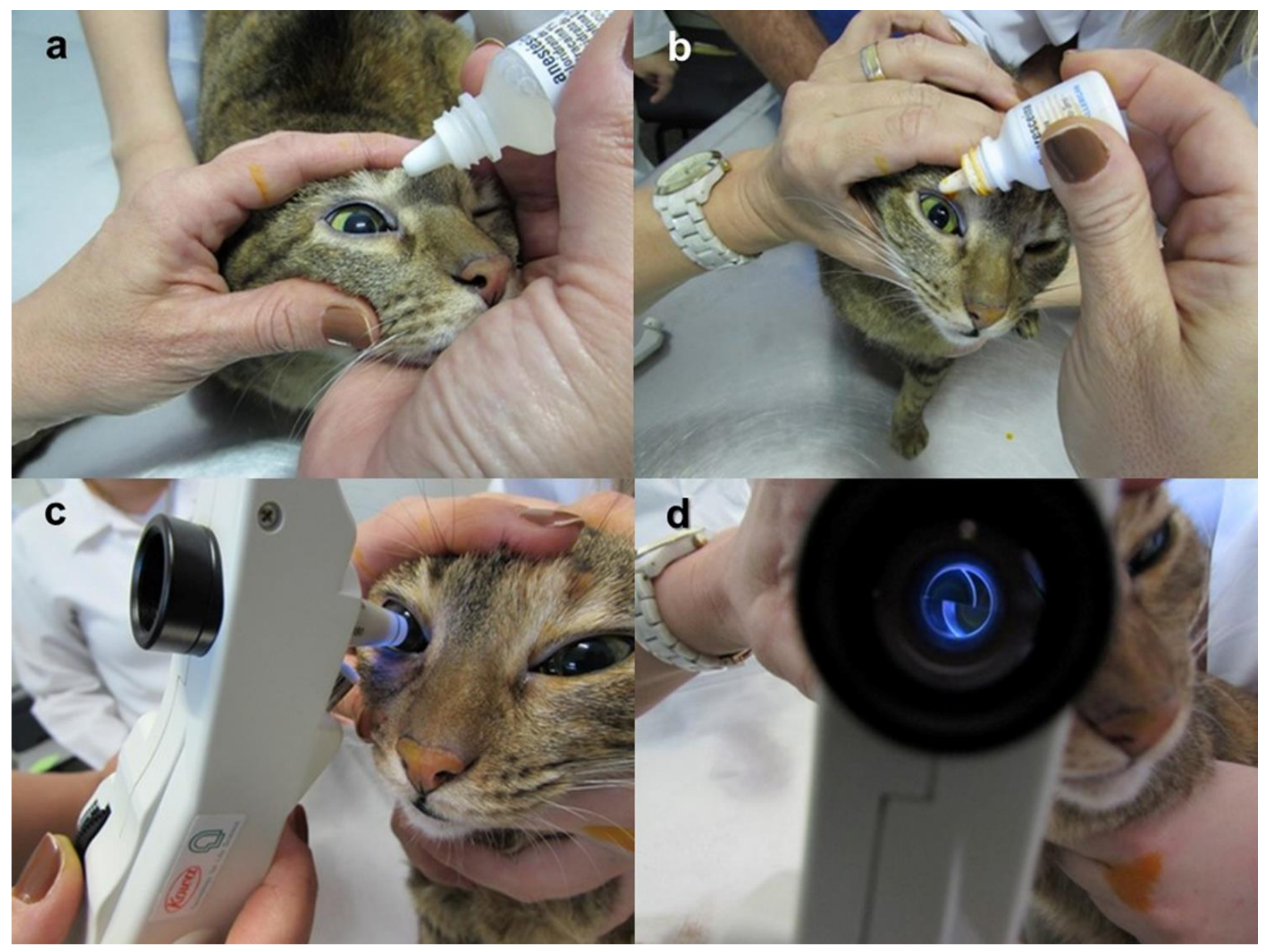

\section{Statistical analysis}

The mean IOP values measured using ocular manometry and tonometry in the ex-vivostudy were used to create a calibration curve. Linear regression analysis was performed to analyze the relationship between the ex-vivostudy manometry and tonometry IOP measurements, and the correlation coefficient $\left(\mathrm{r}^{2}\right)$ was calculated. The manometer and tonometer readings measured in vivo study were compared and analyzed with Student's t-tests. The significance level of $\mathrm{P}<0.05$ was adopted. The Bland-Altman assessment of agreement was used to compare the two methods of IOP measurement. A range of agreement was defined as the mean bias \pm 2 standard deviations.

\section{Results}

The correlation coefficient between the aneroid manometer and the Kowa HA-2 tonometer in cats was $r^{2}=0.993$, and the linear regression equation was $y=0.0915 x+0.0878$, where $y=$ the IOP reading with the tonometer, and $\mathrm{x}=$ real IOP reading in $\mathrm{mmHg}$ (Figure 2). The Bland-Altman plot comparing the intraocular pressure (IOP) readings in $\mathrm{mmHg}$ of manometer and Kowa HA-2 tonometer is shown in figure 3 . 
Figure 2. Comparison of the IOP measurements between manometry (aneroid manometer) and tonometry (Kowa HA-2 tonometer) in theex-vivostudy in cats $(\mathrm{n}=5)$. The solid line is the calculated regressionline, and $\mathrm{r}^{2}$ is the correlation coefficient.

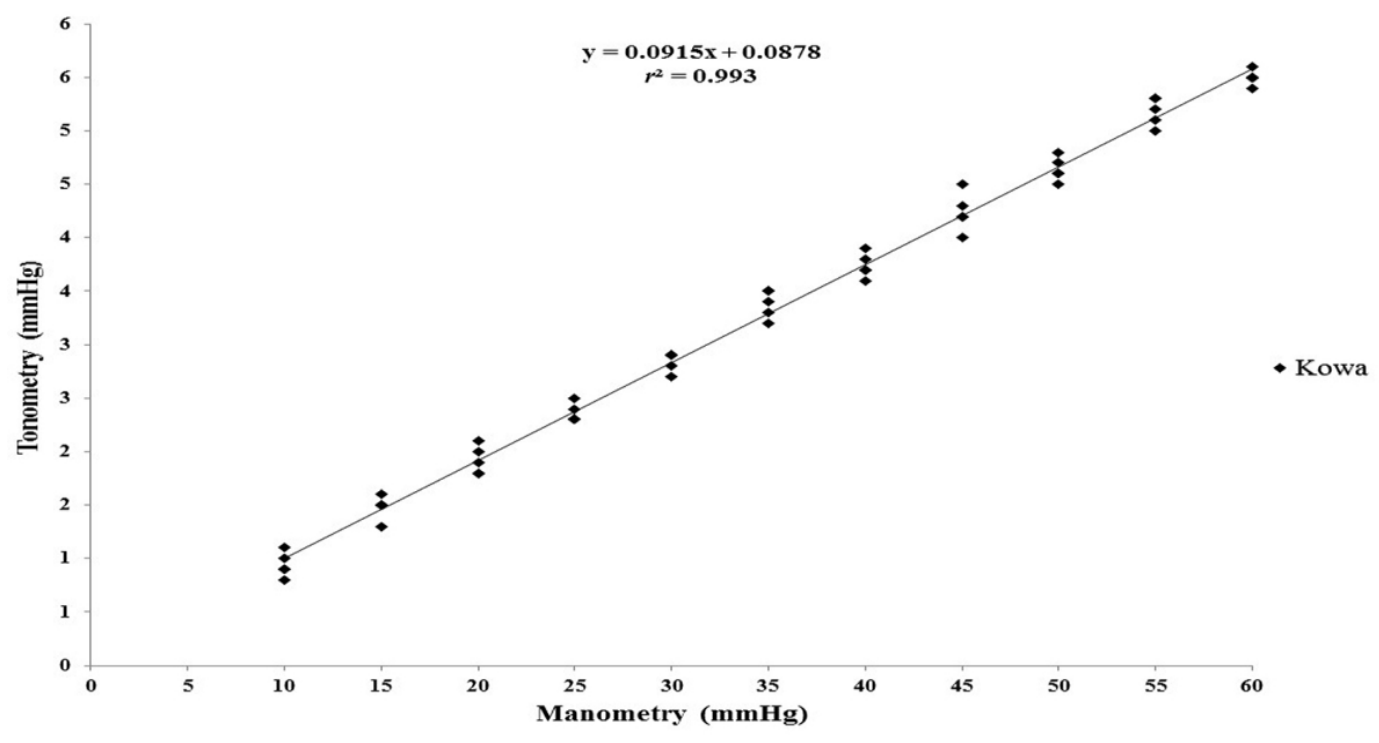

Figure 3. Bland-Altman plot comparing the intraocular pressure (IOP) readings in mmHg of manometer and Kowa HA-2 tonometer.

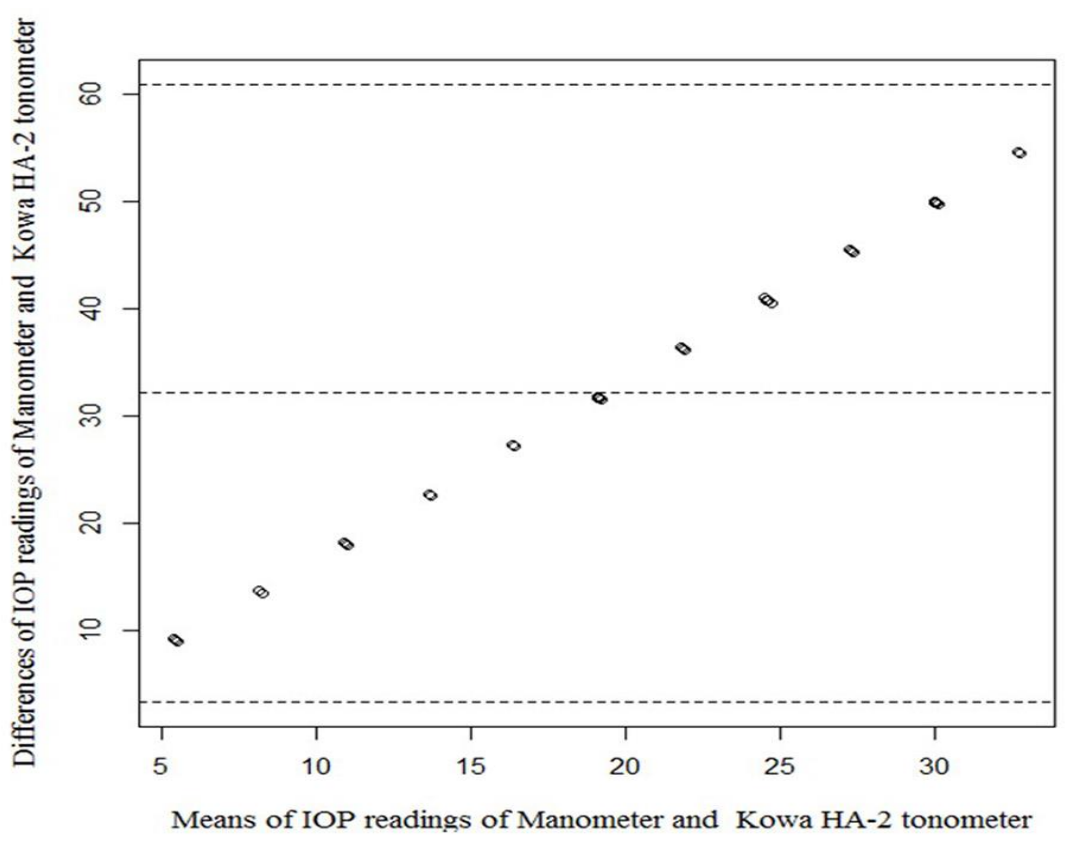


In the in vivo study, the mean IOP value measured in cats using the aneroid manometer was $15.6 \pm 1.1$ $\mathrm{mmHg}(14.0-17.5)$ and that using the Kowa HA-2 tonometer was $15.5 \pm 1.2 \mathrm{mmHg}(13.5-17.2)$. There was no statistically significant difference $(\mathrm{p}>$ $0.05)$ between the values.

In the ambulatory study, the mean IOP value measured with the Kowa HA-2 tonometer of the healthy cats with healthy eyes was $15.0 \pm 1.5$ $\mathrm{mmHg}(11.8-18.3)$, and the mean IOP values for the eyes with clinical signs of glaucoma and uveitis were was $38.4 \pm 8.1 \mathrm{mmHg}(29.6-53.7)$ and $10.4 \pm$ $2.0 \mathrm{mmHg}(5.3-12.2)$, respectively.

\section{Discussion}

The ex-vivo study demonstrated an excellent correlation coefficient between the aneroid manometer and the Kowa HA-2 tonometer $\left(\mathrm{r}^{2}=\right.$ 0.993 ) in cats (Figures 2 and 3), and these results are similar to those found in a study of dogs (ANDRADE et al., 2016). This correlation is also similar to those from studies in cats with the Perkins tonometer $\left(r^{2}=0.988\right)$ (ANDRADE et al., 2009) and $\left(r^{2}=0.905\right)$ (ANDRADE et al., 2012) using the same Goldmann methodology and those of a comparative study using a Tonopen applanation tonometer $\left(r^{2}=0.94\right)$ and a Tonovet rebound $\left(r^{2}=\right.$ 0.92) (MCLELLAN et al., 2013).

The linear regression equation was $y=$ $0.0915 \mathrm{x}+0.0878$, where $\mathrm{y}=$ the IOP reading with the tonometer, and $\mathrm{x}=$ the real $\mathrm{IOP}$ in $\mathrm{mmHg}$ (Figure 2). This equation can be rearranged as performed with $\mathrm{x}=(\mathrm{y}-0.0878) / 0.0915$. Therefore, for an IOP reading 1.6 for example, the tonometer reading would equal $x=(1.6-0.0878) / 0.0915=16.0$ $\mathrm{mmHg}$. Therefore, an IOP reading measured with a Kowa HA-2 tonometer can be approximated by multiplying it by 10 , which is similar to findings in humans (SCHOTTENSTEIN, 1996), other studies that used Perkins tonometers in dogs, cats, horses and bovines (ANDRADE et al., 2009; ANDRADE et al., 2011; ANDRADE et al., 2012; ANDRADE et al., 2013), and a study that used a Kowa HA-2 tonometer in dogs (ANDRADE et al., 2016).

In the in vivo study, the mean IOP value measured in cats using the aneroid manometer was $15.6 \pm 1.1$ $\mathrm{mmHg}(14.0-17.5)$ and that using the Kowa HA-2 tonometer was $15.5 \pm 1.2 \mathrm{mmHg}(13.5-17.2)$; there was no statistically significant difference ( $p>0.05$ ) between the values, which indicates that the tonometer produced IOP measurements that were very close to the actual IOPs. These findings are similar to those obtained in an in vivo study conducted with a Perkins tonometer $(16.4 \pm 2.6$ $\mathrm{mmHg})$ and with manometry $(15.0 \pm 1.7 \mathrm{mmHg})$ in this species (ANDRADE et al., 2009; ANDRADE et al., 2012).

The mean IOP value measured with the Kowa HA-2 tonometer in the ambulatory study of healthy cats with healthy eyes was $15.0 \pm 1.5 \mathrm{mmHg}(11.8$ to 18.3 ), which is similar to the result obtained with a Perkins tonometer $(15.5 \pm 1.3 \mathrm{mmHg})$ in a comparative study using a Tono-Pen XL tonometer $(16.8 \pm 3.6 \mathrm{mmHg})$ (ANDRADE et al., 2012).

IOP values above the normal range are indicative of glaucoma, and values below the normal range are indicative of uveitis (COLITZ, 2005; MCLELLAN; MILLER, 2011; SHUKLA; PINARD, 2012; MILLER, 2013; STILES, 2013), which agrees with the observations of this study. In the ambulatory study, the mean IOP value measured with the Kowa HA-2 tonometer for the eyes with clinical signs of glaucoma was $38.4 \pm 8.1 \mathrm{mmHg}(29.6-53.7)$, which was above the measured value in the healthy eyes $(15.0 \pm 1.5 \mathrm{mmHg})$. In the study of eyes with signs of uveitis, the measured value was $10.4 \pm 2.0$ $\mathrm{mmHg}(5.3-12.2)$, which was below that measured in the healthy eyes.

The IOP values measured with manometry observed in ex vivo and in vivo studiesand their correlation with the values measured with tonometry demonstrate an excellent accuracy in IOP readings by the Kowa HA-2 tonometer. In the ambulatory study, the IOP values obtained with the tonometer 
were consistent with those expected for cats with healthy eyes and eyes with clinical signs of glaucoma and uveitis. Thus, we conclude that the Kowa HA-2 tonometer can be used in the measurement of IOP in cats, since it is a practical and accurate method in this species.

\section{Acknowledgements}

The authors thank the post-graduate program of UNOESTE for financial support.

\section{References}

ANDRADE, S. F.; CREMONEZI, T.; ZACHI, C. A.; LONCHIATI, C. F.; AMATUZZI, J. D.; SAKAMOTO, K. P.; MELLO, P. A. Evaluation of the Perkins ${ }^{\circledR}$ handheld applanation tonometer in the measurement of intraocular pressure in dogs and cats. Veterinary Ophthalmology, Oxford, v. 12, n. 5, p. 277-284, 2009.

ANDRADE, S. F.; KUPPER, D. S.; PINHO, L. F.; FRANCO, E. C.; PRATAVIERA, M. V.; DUARTE, R. R.; JUNQUEIRA, J. R. Evaluation of the Perkins handheld applanation tonometer in horses and cattle. Journal of Veterinary Science, Seoul, v. 12, n. 2, p. 171-176, 2011.

ANDRADE, S. F.; PALOZZI, R. J.; GIUFFRIDA, R.; CAMPOS, R. J. de; SANTOS, G. C.; FUKUI, R. M. Comparison of intraocular pressure measurements between the Tono-Pen $\mathrm{XL}^{\circledR}$ and Perkins ${ }^{\circledR}$ applanation tonometers in dogs and cats. Veterinary Ophthalmology, Oxford, v. 15, p. 14-20, 2012. Supplement 1.

ANDRADE, S. F.; PALOZZI, R. J.; ROLIM, R. D.; JUNQUEIRA, J. R. C.; VALLE, H. F.; SILVA, M. K.; MAIA, M. A.; ZAMPIERE, R. A. Intraocular pressure measurements with the Tono-Pen $\mathrm{XL}^{\circledR}$ and Perkins ${ }^{\circledR}$ applanation tonometers in horses and cattle. Ciência Rural, Santa Maria, v. 43, n. 5, p. 865-870, 2013.

ANDRADE, S. F.; ANDRADE, A. L.; KANASHIRO, G. P.; SILVA, D. A.; BARBERO, R. C.; KUHN, J. M. P.; SILVA, A. C. Ex vivo and in vivo study of Kowa HA-2 applanation tonometer in the measurement of intraocular pressure in dogs. Semina: Ciências Agrárias, Londrina, v. 37, n. 2, p. 797-806, 2016.

COLITZ, C. M. Feline uveitis: diagnosis and treatment. Clinical Techniques in Small Animal Practice, Philadelphia, v. 20, n. 2, p. 117-20, 2005.
DEL SOLE, M. J.; SANDE, P. H.; BERNADES, J. M.; ABA, M. A.; ROSENSTEIN, R. E. Circadian rhythm of intraocular pressure in cats. Veterinary Ophthalmology, Oxford, v. 10, n. 3, p. 155-161, 2007.

ELMALLAH, M. K.; ASRANI, S. G. New ways to measure intraocular pressure. Current Opinion in Ophthalmology, Philadelphia, v. 19, n. 2, p. 122-126, 2008.

FEATHERSTONE, H. J.; HEINRICH, C. L. Ophthalmic examination and diagnostic. In: GELATT, K. N.; GILGER, B. C.; KERN, T. J. Veterinary ophthalmology. Iowa: Willey-Blackwell, 2013. p. 533-613.

KROLL, M. M.; MILLER, P. E.; RODAN, I. Intraocular pressure measurements obtained as part of a comprehensive geriatric health examination from cats seven years of age or older. Journal of the American Veterinary Medical Association, Ithaca, v. 219, n. 10, p. 1406-1410,2001.

LEE, J. Y.; HA, S. Y.; PAIK, H. J.; KWON, K. Y.; KIM, Y. Y. Morphologic changes in trabecular meshwork after patterned and argon laser trabeculoplasty in cats. Current Eye Research, London, v. 39, n. 9, p. 908-916, 2014.

LINGEL, N. J.; COFFEY, B. Effects of disinfecting solutions recommended by the centers for disease control on Goldmann tonometer biprism. Journal of American Optometrists Association, St. Louis, v. 63, n. 1, p. 43-48, 1992.

MAGGS, D. J. Basic diagnostic techniques. In: MAGGS, D. J.; MILLER, P.; OFRI, R. Slatter's fundamentals ofveterinary ophthalmology. St. Louis: Saunders Elsevier, 2013. p. 79-109.

MCLELLAN, G. J.; KEMMERLING, P.; KILAND, J. A. Validation of the TonoVet ${ }^{\circledR}$ rebound tonometer in normal and glaucomatous cats. Veterinary Ophthalmology, Oxford, v.16, n. 2, p. 111-118, 2013.

MCLELLAN, G. J.; MILLER, A. E. Feline glaucoma - a comprehensive review. Veterinary Ophthalmology, Oxford, v. 14, p. 15-29, 2011. Supplement 1.

MILlER, P. E. The glaucomas. In: MAGGS, D. J.; MILLER, P.; OFRI, R. Slatter's fundamentals of veterinary ophthalmology. St. Louis: Saunders Elsevier, 2013. p. 227-255.

MILLER, P. E.; PICKETT, J. P.; MAJORS, L. J.; KURZMAN, I. D. Evaluation of two applanation tonometers in cats. American Journal of Veterinary Research, Chicago, v. 52, n. 11, p. 1917-1921, 1991. 
OFRI, R.; SHUB, N.; GALIN, Z.; SHEMESH, M.; SHORE, L. S. Effect of reproductive status on intraocular pressure in cats. American Journal of Veterinary Research, Chicago, v. 63, n. 2, p. 159-162, 2002.

OKAFOR, K. C.; BRANDT, J. D. Measuring intraocular pressure. Current Opinion in Ophthalmology, Philadelphia, v. 26, n. 2. p. 103-119, 2015.

PASSAGLIA, C. L.; GUO, X.; TROY, J. B. TonoPen $\mathrm{XL}^{\circledR}$ calibration curves for cats, cows and sheep. Veterinary Ophthalmology, Oxford, v. 7, n. 4, p. 261-264, 2004.

SCHOTTENSTEIN, M. S. Intraocular pressure andtonometry. In: RITCH, R.; SHIELDS, M. B.; KRUPIN, T. The glaucomas - basic sciences. St. Louis: Mosby,1996. p. 407-428.

SHUKLA, A. K.; PINARD, C. L. Feline uveitis. Compendium: Continuing Education for Veterinarians, Yardley, v. 34, n. 9, E1, 2012.

STILES, J. Feline ophthalmology. In: GELATT, K. N.; GILGER, B. C.; KERN, T. J. Veterinary Ophthalmology, Iowa: Willey-Blackwell, 2013. p. 1477-1559.
STRUEBING, F. L.; GEISERT, E. E. What animal models can tell us about glaucoma. Progress in Molecular Biology and Translational Science, Amsterdam, v. 134, p. 365-380, 2015.

TEIXEIRA, L. B.; BUHR, K. A.; BOWIE, O.; DUKE, F. D.; NORK, T. M.; DUBIELZIG, R. R.; MCLELLAN, G. J. Quantifying optic nerve axons in a cat glaucoma model by a semi-automated targeted counting method. Molecular Vision, Atlanta, v. 20, p. 376-385, 2014.

VINCENT, S. J.; VINCENT, R. A; SHIELDS, D.; LEE, G. A. Comparison of intraocular pressure measurement between rebound, non-contact and Goldmann applanation tonometry in treated glaucoma patients. Clinical and Experimental Ophthalmology, Carlton, v. 40, n.4, p. 16370, 2012.

XU, G.; WEINREB, R. N.; LEUNG, C. K. Optic nerve head deformation in glaucoma: the temporal relationship between optic nerve head surface depression and retinal nerve fiber layer thinning. Ophthalmology, Rochester, v. 121, n. 12, p. 2362-70, 2014. 
